Marquette University

e-Publications@Marquette

4-1-2018

\title{
Deconstructing the Dogma of Domesticity: Quaker Education and Nationalism in British Mandate Palestine
}

Enaya Othman

Marquette University, enaya.othman@marquette.edu

Accepted version. Journal of Colonialism and Colonial History, Vol. 19, No. 1 (Spring 2018). DOI. (C) 2018 Enaya Hammad Othman and The Johns Hopkins University Press. Used with permission. 
Marquette University

\section{e-Publications@Marquette}

\section{Foreign Language Faculty Research and Publications/College of Arts and Sciences}

This paper is NOT THE PUBLISHED VERSION; but the author's final, peer-reviewed manuscript. The published version may be accessed by following the link in the citation below.

Journal of Colonialism and Colonial History, Vol. 19, No. 1 (Spring, 2018). DOI. This article is (C) Johns Hopkins University Press and permission has been granted for this version to appear in $\underline{\mathrm{e}}-$

Publications@Marquette. Johns Hopkins University Press does not grant permission for this article to be further copied/distributed or hosted elsewhere without the express permission from Johns Hopkins University Press.

\section{Contents}

Abstract.

\section{Deconstructing the Dogma of Domesticity: Quaker education and nationalism in British Mandate Palestine}

\section{Enaya Hammad Othman}

Department of Foreign Language, Marquette University, Milwaukee, WI

\section{Abstract}

This paper focuses on the Friends Girls School (FGS) in Ramallah as a site of interaction between Americans and Palestinians during the British Mandate between 1920 and 1947. It draws on extensive archival records as well as Palestinian students' writings and oral accounts to trace how Quakers' 
education and the nationalist discourse in the country influenced the students' personal and national identities. Palestinian students utilized Quaker education as a springboard for the subversion of gendered religious, political and Orientalist discourses which were prevalent during this time period.

American Quaker missionaries founded the Girls Training Home (GTH), known as Friends Girls School (FGS) after World War I, in 1889. Their values of peaceful coexistence, academic preparation, domestic training, and community service and engagement shaped the students' personal and national identities. Like other Western missionaries, they held a universal perception of their role as those who would enlighten and uplift Palestinians. They perceived Palestinian women as victims of social and cultural degradation and in need of rescue. Nevertheless, the process of producing educated mothers and wives brought with it a complicated discourse that enabled FGS students to argue for and design their role in an anticolonial and nation-building context. They utilized Quaker education to transform their traditional roles within the home, while demanding the right to claim public spaces as teachers and members of charitable organizations. This led them to play active roles in the nationalist movement and to advocate for gender and cultural equality within Palestinian society. They also internalized Quaker ideals of internationalism and nonviolent means of conflict resolution, which motivated them to support unity across tribal and religious lines.

Along with archival, institutional and personal collections, as well as the oral interviews I conducted with formal FGS students, $\underline{-}$ this study benefits from the work of a number of postcolonial scholars, including Ellen Fleischmann, Barbara Reeves-Ellington, Heather Sharkey, Inger Marie Okkenhaug, Afsaneh Najmabadi, Beth Baron and Ussama Makdisi. They emphasized the role missionary schools played in providing modern education to the local population, but also as sites for cultural penetration and conversion. ${ }^{-}$Missionary activities increased after the mid-nineteenth century due to Ottoman Tanzimat reforms that allowed the opening of Western institutions in the Ottoman Empire. $\underline{3}$ Along with its geopolitical importance, the religious significance of Palestine made it a center of attention for missionaries, archaeologists, tourists, travelers and consuls who perceived Palestine as a Christian place controlled by the evil Muslim Ottomans and in need of rescue. ${ }^{4}$ By the turn of the twentieth century, 1,300 missionary schools operated in Palestine and Syria. ${ }^{5}$ Christian students constituted the majority in these schools along with a substantial number from Muslim middle and upper class families. Western missionaries achieved great success in educational and medical enterprises, but not religious conversion; Quakers were able to convert only a handful of Palestinian families. Other missions, such as the Swedish Salaam Mission in Egypt and the Church Missionary Society among Muslims in Sudan failed in converting the local population. Likewise, in Lebanon, locals challenged missionary attempts at conversion with opposition led especially by the leaders of different religious communities. ${ }^{-}$In Palestine, the Muslim Supreme Council (MSC), al-Hay'ah al-Islamyya al- 'Uya, worked earnestly to combat missions' conversion attempts among the local population. ${ }^{?}$ Nevertheless, beginning in the late nineteenth century, American missionaries' educational endeavors succeeded in influencing the cultural and social developments of the region. These endeavors are epitomized in some of the colleges and schools that are still operational today, including the American Quaker schools in Ramallah, Palestine, and the American universities in Lebanon and Cairo.

\section{Ramallah Mission and Education under the British}

The British replaced the Ottomans and occupied Palestine during World War I, and by 1920,

they legally ruled the country under the mandate system. The British policies, especially in the aftermath 
of the Balfour Declaration of 1917 (in which the British foreign minister, Lord Arthur Balfour, proclaimed his government's support for the establishment of "a Jewish national home in Palestine") and Britain's role in facilitating immigration and land transference to the European Jews, outraged Palestinians. The Palestinian struggle in this colonial context culminated in the General Strike and the Great Arab Revolt from 1936 to 1939.. Arab nationalists and academics including George Antonius, a former assistant director in the Department of Education under the mandate, criticized the British policies and control of the Arab educational system in Palestine. $\stackrel{-}{ }$ The British created two public educational systems based on racial and linguistic features: one used Arabic as a medium of instruction and the other used Hebrew for Jewish schools. These systems continued to develop until the end of the mandate period in 1948 . This was "in spite of the fact that one system was made for an overwhelming Arab majority of 93 percent and other system was made for a small minority." However, unlike the Arab school system, the Jewish community controlled its public education and was free to create its own curricula based on its own national aspirations and political agendas. $\frac{10}{}$ According to the 1931 census, the Arab population totaled 850,559 and the Arab public schools provided education to approximately 20,288 students, with only 942 of those being girls. The private Muslim and Christian schools provided education to an additional 23,797 students while 79,544 children still remained without any education. $\underline{\underline{11}}$

Before 1856, the population of Ramallah, located ten miles north of Jerusalem, was entirely Greek Orthodox. In that year, the Roman Catholic Church opened a boys' school followed by one for girls in 1873 opened by the Sisters of St. Joseph. By 1904, the Ramallah population had reached four thousand, of which the Greek Orthodox were still the majority. $\underline{12}$ The Quaker mission in Ramallah began in 1867 as an individual initiative of Eli and Sybil Jones, who visited the town and upon local request funded the first of several Quaker day schools in the Ramallah region. By 1873, fifty girls attended these schools. In 1889, the Friends Girls School (FGS) was established as a boarding school (called then the Girls Training Home [GTH]), followed in 1901 by the Friends Boys School (FBS)-named at the time the Boys Training Home. $\underline{13}$ Between 1889 and 1909, the GTH received 141 new female students, who stayed at the school for an average of five years. After 1919, enrollment of both day and boarder students at FGS fluctuated between 100 and 180 students, of which 80 percent were boarder students; until the late 1930s the majority of them were Palestinian Christians. However, after 1940 the number of Muslim students increased significantly, reflecting demographic changes, increased migration among Palestinian Christians, and the limited choices of girls' secondary schools, which encouraged Muslim families to send their daughters to FGS. During 1944, there were 89 boarder students, with 49 of them being Muslims. From 1945 to 1946, there were 267 students enrolled; among them were 68 Muslims and the rest Christians from different denominations (118 Greek Orthodox, 25 Catholic, 56 Protestants)..$\underline{14}$

With the rise of Palestinian nationalism and the emergence of an urban, educated, upper and middle class, nationalist feelings impelled increased standards of education in schools. The introduction of Arabic language and literature in mission schools was not specific to the FGS, but part of a general discourse present in other schools. A number of writers who have dealt with education and mission schools in Palestine point out that schools such as the Jerusalem Girls College wanted to compete with boys' schools and to train the girls in both modern domestic science and academic education. ${ }^{15}$ Modern curricula encouraged higher education beyond primary pedagogy in both public and private schools.

Common subjects for girls were science, mathematics, hygiene, history and geography, botany, physical education, drawing, and home economics. At the FGS, in the preparatory classes, Arabic was the language of instruction and English was taken as a second language class, while all subjects in the 
secondary classes were taken in English. $\frac{16}{}$ The emphasis on these subjects, including the English language, was important as the "doorway to higher education" and college preparatory exams..$^{17}$

Since the late nineteenth century, cultural and social transformations continued to alter the Arab societies. The notion of preparing young girls for their national role as fit mothers of the nation's new generation was a discourse that occupied many writers of the nahda (a pan-Arab cultural revival and intellectual movement). Arab women writers, including those in the women's press such as Hind Nufal (1860-1920), Rose Haddad (1903-30) and Labeba Hashim (1906-39), created sixty-two journals and magazines during the first half of the twentieth century. These women adopted the same discourse of womanhood as male nahda writers. They "initially justified girls' education on the ground that the nation would advance, if mothers and wives were better prepared for religious and domestic roles." Thus, the women's press in particular called for improvements in the domestic sphere, which "was seen as the best strategy for raising women's status, and the outpouring of domestic literature instructing the wife, mother, and 'mistress of the house."' Moreover, "domestic work became professionalized with its own schools, texts, journals, and a jargon" as historian Beth Baron contends. $\frac{18}{}$ Palestinian newspapers also were voices for modernity. Their numbers mounted to thirty-four by the outbreak of WWI. $\underline{19}$ For example, two Jaffa-based newspapers that were distributed and read throughout Palestine, Filastin, alKarmil and al-Difa', both promoted the modernization of Palestinian life through furniture and clothesespecially among the middle and upper classes. $\underline{\underline{20}}$

In the context of these changes, and in combination with modernizing material living, women's conception of their roles and limitations evolved. The American Quakers explained this new atmosphere and the role the FGS should play, saying:

With the changes that have been coming so rapidly in the last two decades, the life of women has broadened.... There are magazines for women and the news of the big outside world is common news. And while all this means that life is growing bigger for our women, it is not always growing in the right way and they have as yet learned very little about the joy and duty of service for others. Every girl in our school ought to get a vision of the work that is waiting for her in her own village or city. $\underline{\underline{11}}$

Though the Quakers' Ramallah Mission can be described, to a large degree, as a colonial site where the relationship between Palestinians and American missionaries, who operated the site at different stages, was never equal, it still served "as an arena of exchange."르 The cultural exchange between American Quaker women and Palestinians altered the lives of both groups. Their encounter reflects a combination of cross-cultural exchanges accompanied by tensions, which motivated the missionaries to attempt to rework strategies in order to function effectively with the Palestinians.

\section{Palestinian Students Negotiating National and Gender Identity}

Palestinian girls took full advantage of the educational opportunities and were able to transform their gender roles, while refiguring the place of the American missionary schools in the heart of a Palestinian town. As a result, they were able to form an identity that was neither identical to nor totally removed from their missionary teachers or their Arab culture. For example, they were receptive to Western dress codes and modern education, but they maintained their religious convictions and viewed the Quakers' Christian values of simplicity, peace and compassion as universal and already existing within their Indigenous communities. The influence of Quaker education shaped their views of gender 
and nationalism and allowed them to advocate for postsecondary education and negotiate the ongoing social and cultural changes that affected their roles at home and in the public sphere. In the colonial context of Palestine, public, private and mission schools that instructed both Arab Christian and Muslim students played an important role in the evolution of the women's movement and its womanhood nationalist politics. The gendered education Palestinian girls received accorded with nationalist and modernist anticipations of their role as educated mothers and wives. $\underline{23}$

This also colluded with the British aims of educating Palestinian girls. The British director of education between 1920 and 1936, Humphrey Bowman, "emphasized the importance of educating Arab girls in domestic skills over book leaning," and thought girls needed only some elementary education. $\underline{24}^{4}$

Home economics at FGS became a modernizing project connected to professionalism in managing household affairs and empowered women by transforming their traditional role as mother and wife to "manager of the house." $\underline{25}$ Acquiring these skills entitled women to become their husband's partner and, in some cases, the sole head of the household in managing the family's budget and expenses. This training was endorsed by leaders of the male-dominated nationalist movement who believed that it would equip upper and middle class women to be "self-sufficient and independent rather than reliant on household help," and would also provide modern household skills for poor women, who could use them to earn a living. $\underline{26}$ "Womanhood, not scholarship, is the first aim of education," noted Palestinian students at the FGS in their school's newsletter, the New Light. $\underline{27}$ This statement reflects how the students' Quaker education reinforced the primacy of their roles as wives and mothers, roles that overlapped with the Arab/Palestinian ideals of womanhood and with the qualities that the Palestinian national movement valued in mothers of the nation's new citizens.

Not only did the home economics classes teach valuable skills, but they also reinforced prevalent gender roles and ideologies. Many students saw home economics as the most significant aspect in the FGS education because they envisioned themselves as primarily mothers and wives. Scientific education that pertained to students' home life such as botany, gardening, and identifying wildflower and plant specimens was employed to reinforce the girls' gendered notions towards the domestic sphere.

Examples in the students' writings from Donn Hutchinson's private collection describe the impact that home economics had on their agency within the home. Zahia Durbas (class of 1927) details the way in which mathematical skills enabled the managing of household income. Durbas believed that all schools in Palestine should assign a home management program because of its equal importance to other school subjects..$\underline{28}$ Tafida Tarazi (class of 1931) highlights the importance of home economics, particularly house management, child rearing, sewing and nursing, showing the students' thinking. ${ }^{29}$ In her essay titled Hayaty wal-Far 'al Manzeli ("My Life and Home Economics"), she includes a poem that depicts the students' thought about their school and the education in home economics they received:

I swear, my dear school,

You awakened the best scent of my spirit, Taught me to manage my dwelling And beautify myself with high qualities.

The beating of my heart is from the tenderness of yours, Its softness like the elasticity of a breeze.

When I was a youngster a seedling of virtue you planted 
And today I am blossoming, and here are my flowers:

Knowledge, virtues, housekeeping

All are the only lady's life armament. $\underline{30}$

The home economics classes taught valuable skills that revolved around ideologies of genderidentity construction, skills that women could carry with them throughout their adult, married lives. Furthermore, it allowed the students to maximize their role in the home by incorporating such skills. Nazeha Abdul Jawad, a Muslim student who attended the FGS between 1937 and 1945, emphasized that same point in her interview, indicating that she valued home management because it helped her budget her household income satisfactorily, especially since her husband was on a fixed income. 11 Jawad indicated that the training she received in home economics was helpful in maintaining her marriage and described her home as "simple but neat." She made many things for her house, including curtains for the windows, and applied simple but elegant decorative items she had learned about in her classes. The training girls received in home economics classes cultivated feminine identities for modest, nurturing and family-focused mothers; simultaneously, it gave women a greater sense of purpose and empowerment in the household. .22

Zahia Durbas (class of 1927) demonstrated the importance of an empowering domestic role for women as she described the three important components of household management, namely economics, art and health, that were the responsibilities of the women. Women who were adept at mathematical skills as a result of education were best equipped to manage the household income, with budget priorities being children's education and medical expenses. Women also needed to prioritize a healthy diet for the children as well as hygiene. However, another important priority within the household budget was travel (safar). According to Durbas, seeing the world would provide children with important knowledge and she used her authority as the household manager to create a new tradition in her household, at a time when an annual vacation was unusual even for middle-class Palestinians.

Despite the focus on training women to be good wives and mothers, a Quaker education carried with it an emancipatory tendency which the students translated to their role in nation building. Palestinian women at missionary schools found ways to advocate for gender equality and participate in politics. By preparing the girls to be global citizens and peacemakers, the FGS gave them access to worldwide information such as women's struggles both in the Arab world and the West, which in turn enabled them to envision their right to have a political role in the national movement.

The FGS students used the information they knew about women's accomplishments as examples to suggest and call for the participation of women in the political sphere. For example, Katrina Hallaby (class of 1927) believed that "women were equal to men and thus capable of doing the same kinds of work; she compared the positions of women in the Arab world to those in the West in her graduation essay, particularly emphasizing the political opportunities that were becoming available to women in the United States. She mentioned that some had even become governors, alluding to Nellie Taylor Ross, a Wyoming Democrat who was elected in 1924. Hallaby's writing displays an awareness of women's positions in various countries, which enabled her to compare Palestine and other Arab and Muslim societies such as Turkey, Egypt and Syria with America and the West. At the time of Hallaby's writing, opportunities for women in Palestine were very limited, and she wrote emphatically about the need to make education and job training available so women would be able to participate in the 
workplace outside of traditional gender restrictions that limited them to teaching, nursing and secretarial work. Unlike many of her peers and teachers, Hallaby argued that women should have the same rights and opportunities in life as men, including access to political positions so as to actively work for family laws to benefit women and children. $\underline{33}$

The Palestinian students used their training in social services to call upon their municipalities for reforms to establish a healthy environment with better sanitation of their streets and public areas. ${ }^{34}$ Hallaby's view should be seen as part of the general atmosphere in the country, where an active women's movement was able to hold its first Arab Women's Congress in Jerusalem in 1929. Over two hundred delegates attended the Congress from all parts of Palestine. $\frac{35}{3}$ Because students were exposed to women's activism through movies, women's magazines and newspapers such as al-Karmil, al-Defa', and Falestine, they were able to sustain a discourse that helped them come to terms with challenging ideas like those espoused by Hallaby herself.

Likewise, Muhja Saba's essay Luzum Ta leem al-Fatah fi Falasteen ("The Necessity of Educating the Girls in Palestine"), and Najla Taqtaq's essay 'an al- 'Ulum al 'Uliyya Muhemah li al-Bint wa sabi ("Higher Education is as Important for Girls as for Boys"), both dealt with women's rights to education and equal opportunities to enter the public sphere. Their essays attributed Western superiority in the sciences and literature to women's contributions to these fields and their active participation in public, scientific and artistic discourses and projects. Some Palestinian girls saw Western women as already having achieved gender equality during the 1920s, or at the very least as making more advances than Arab women. However, they understood gender equality to mean equal access to education and jobs; they did not associate the social and sexual freedoms demanded by Western women with the equal rights that they sought out.

There was a greater degree of Arab consciousness of and resistance to Eurocentric feminist discourses among students in public schools because Arabic was the language of instruction and the form of education emphasized Arabic literature and Arab and Islamic history. $\frac{36}{}$ Women's writings that were introduced were most often from contemporary publications such as those written by the Palestinian Lebanese writer Mayy Ziyada's al-Muqtataf, who published in 1924 to acknowledge the accomplishment of one of the women nahda writers, the Syrian Warda al-Yaziji. Ziyada's stated goal was "to uncover and register in existence the nature of the eastern woman, and to struggle thereafter to make sure that we help it to grow." $\underline{37}$ At the FGS, elements of Arab nationalism eventually entered the academic sphere. The Arab staff advocated for the introduction of more Arabic language and literature into the curriculum, which in turn sharpened their students' sense of national and cultural identity. $\frac{38}{}$ The Ramallah Mission went a step further and attempted to nationalize the mission by transferring its management to Khalil Totah, one of the first graduates from the FBS. Totah served as a teacher, principal of the FBS and secretary of the Mission between 1927 and 1944, and he played an instrumental role in making Arabic language and literature an integral part of the school curriculum, especially in the $1930 \mathrm{~s} . \frac{39}{}$ The attempt was not successful then but speaks of the heightened national atmosphere of the period.

Many students emphasized the role played by their Arab teachers in agitating for Arab nationalism. Wadia Shatara, a long-time Arab staff member who taught Arabic for the secondary classes, knew English well and was loved by both American teachers and Palestinian students. $\stackrel{40}{-}$ The American teachers described her as an invaluable source of information about Palestinian and Arab history and 


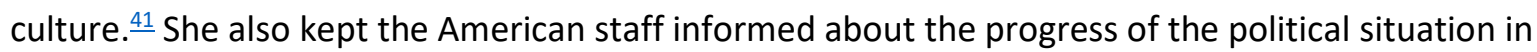
Palestine from an Arab viewpoint. Aida Audi explained that most of the students' information about the Palestinian national cause came from teachers such as Miss Shatara and Miss Faris. She said, "We learn from our Arab teachers national songs such as Mawteny ("My Country")," written by the Palestinian poet, Ibrahim Toqan. While they were an important means of cultural contact for the missionary teachers, Arab teachers such as Miss Shatara, Miss Faris, Miss Zahran and Miss Daud were described by their Palestinian students as "nationalists," and their knowledge and influence helped shape the hybridized identities and ideologies of these students. Serene al-Husseini Shahid, who attended the FGS in the 1930s, mentioned the subjects she studied included English, Arabic, Arithmetic, History and Geography, but that "what I enjoyed most was Literature, both Arabic and English." ${ }^{43}$ By advocating for a revival of the Arabic language, culture and history, the Arab staff consolidated these elements that influenced the students' sense of Arabism.

Luryce Kassab's essay Numw al-Shu 'ur al-Watany ("The Growth of National Sentiments") explains the importance of nationalism and the feelings attributed to nationalism as a unifying principle for people across religious and tribal lines. Like other students, Kassab praises nationalism in the Western world that is based on unity among its citizens regardless of their creeds and locales. She also warns about imitation of the "West in the good and the bad habit without thinking," which would result in "the death of nationalist sentiment" and in the "East" becoming "dependent [on the West] with chains of humiliation and shame." 44 Clearly, some of these girls construed sophisticated understandings of diverse global nationalisms and feminisms.

The girls' exposure to mid-nineteenth- and early twentieth-century ideals of the "new woman" from Western literature, combined with an increased emphasis on Arabic language and literature, played a large part in forming the girls' national and cultural identity. As Arab women became more educated about women's struggles internationally and the different techniques utilized for change, they began to argue for their own reforms. They began to argue for gender equality in education and employment outside their domestic realm. ${ }^{45}$ This opportunity opened many doors for the students' futures and gave them the tools they needed to achieve their goals and occupy positions outside the domestic realm.

The American Junior College in Beirut and the American University of Beirut were attractive destinations for FGS girls who chose to continue their education. Najla Cook, who attended the FGS from 1929 to 1940, indicated that many girls in her graduating class went to the American University of Beirut. $\underline{46}$ The New Light interviewed graduating students and asked them to describe their postgraduation plans. Abla Nashef and Badira Khatib planned to attend the Junior College for two years before returning to Ramallah to teach at a newly opened vocational school for orphaned children. $\frac{47}{}$ Margaret Jubrial reported that she was intending to enroll in college in Beirut and become a kindergarten teacher temporarily until saving some money to pursue higher education in England in order to gain the qualifications and skills needed to open and operate her own kindergarten school. $\underline{48}$ Qismat Abu Laban planned on entering the Junior College for two years in order to specialize in "children's treatment and training" at the American University of Beirut. After graduation, she would return to her hometown of Jaffa, where she would open a clinic, and indicated that she would reserve time every week to travel to the surrounding villages to treat children and to instruct village mothers on how to "improve sanitation and child care." Like most of the others, Lamaat Buseuso planned to go for two years of training at the Junior College, but her ultimate ambition was to earn her bachelor's degree 
and become a medical doctor. Her alternate plan was, like many of her peers, to become a teacher and to write novels in both Arabic and English during her spare time. While many of the students from the class of 1938 indicated interests in teaching, writing and nursing, they also showed a significant desire to be highly capable community leaders in ways that would support the elevation of women, and thus, the progress of Palestinian society. $\underline{49}$

The New Light traces the remarkable progress made by the FGS class of 1939 in the ten years after their graduation. Whereas the previous commencement issue had provided insight into the students' aspirations, this issue described the students' actual outcomes. Among the eleven girls who graduated that year, Bahia Aq il was the only one to complete an advanced degree. She became a wellknown preacher and earned a doctorate of divinity. Similar to the class of 1938, many of the students (Violet Zarou, Maggie Kattan, Hilda Hadadd and Alice Boursalian) became teachers. Victoria Ackall became a small business owner; she opened a women's clothing boutique and hired her fellow student Abla Eid as a clerk. $\underline{50}$

A major factor in the increasing independence of women after the mid-1920s was the introduction of higher educational standards meant to prepare the girls to meet college entrance requirements. As we have seen, Subhiya Makdadi, who graduated from the FGS in 1928, responded to these changes by establishing herself as an academic and career woman while balancing her role as a wife and mother. After she passed the London Matriculation Exam, Makdadi attended the American University of Beirut, married, and pursued a career in teaching while raising her children. She was able to develop a complex and accomplished private and professional life, and she ambitiously took advantage of the educational opportunities available to her. When her children were older, she traveled to the United States for doctoral studies and eventually received her doctoral degree. $\frac{51}{\text { Th }}$ The graduates of the FGS made considerable impact when they assumed public roles as teachers not only in Ramallah and other cities in Palestine, but also in other countries across the Arab world such as in Egypt, Iraq and Transjordan. One of the FGS students who graduated from the American Junior College in Beirut in 1932 took a teaching job in Mosul, Iraq. Two other graduates taught in Jordan, one in the city of Amman and the other in Karak. Other FGS students worked in nursing, office settings, dressmaking, and in charitable and philanthropic institutions such as at the YMCA. ${ }^{22}$ Henriette Siksik (1935) was a particularly accomplished activist who founded the Four Homes of Mercy in the Jerusalem area. She also taught for eleven years during British Mandate Government at Alawieh Girls School in Jerusalem; five years at the American School for Girls in Beirut; two and a half years in the Ministry of Education in Amman, Office of Educational Materials; and two and a half years at the Ministry of Education, Tripoli (Libya) Office of Educational Materials. Siksik also worked on radio broadcasting under the supervision of Ibrahim Toucan, the well-known Palestinian poet, in 1939.

For the students at the FGS, education meant increased independence and effects that impacted girls from all class backgrounds. By late 1920s and into the 1930s, the students' writings consistently showed an increased awareness of how education could be employed to challenge the entrenched values and practices of a well-established patriarchal system by showing targeted disobedience to male authority when feasible and justifiable. As girls graduated from the FGS and a considerable number moved on to college, they began to postpone marriage, therefore improving their marriage prospects. 
Audi explained that she remained single even after she graduated from the American University of Beirut because her expectations had changed drastically. Not only was she able to reject men who asked for her hand, but her education also allowed her to participate in society as an independent individual. However, her decision conflicted with the patriarchal values of some Arab men who thought these college women were either too old or too independent and liberal. Audi emphasized, "Many of the FGS girls who went for higher education did not marry." Another interviewee from the 1948 class, Salwa Tabri, also stayed single, as did her sister. Tabri became an English and music teacher at the FGS before she went to Germany, where she specialized in teaching music. After her return to Palestine, she taught at the Women's Teachers College in al-Tera, Ramallah, and was a director of the Jerusalem choir for almost forty years. $\frac{53}{}$

Many other graduates remained unmarried, including Leila Khoury (class of 1947), who became a professor at the American University of Beirut, and Georgette Shihadeh (1948), a well-known teacher in Ramallah and al-Bireh before her retirement, and an inspector with the Office of Education. Yusra Salah (class of 1942), a daughter of a Muslim sheik, went to the Girls College in Beirut and then to the American University of Beirut, where she graduated in 1946. After working as an English teacher for a few years, she became the superintendent of the Women's Teachers College in Nablus. Ambitious for more education, Salah traveled to the United States, where she studied at Columbia University and received her Master's degree in English in 1953. Yusra remained unmarried and contributed greatly to the educational and intellectual life of Palestine. She wrote English textbooks that were used in the public schools and translated many texts to and from English and Arabic. $\frac{54}{\text { Most }}$ of the girls who did marry were teachers at one point either before or directly after graduation from the FGS, even though this compromised their eligibility for marriage. The tension between their desire for careers and the ingrained standards of their potential partners illustrates the challenges these women faced in subverting the mechanisms of patriarchal authority.

During this time Palestinian upper and middle class women began to organize themselves politically to actively challenge the policies of the British Mandate that promoted the creation of a Jewish state in Palestine. $\underline{55}$ Political education was introduced to the students by Arab teachers and the national and international press. Some students were affected directly by the national politics of the time as their parents and relatives were active in the nationalist discourse. The students were aware of the county's political situation-especially during times of intense upheaval-because of their exposure to the cause from their families and Palestinian newspapers. In one case, the FGS student Serene alHusseini Shahid came from a prominent and notable Palestinian family. Her father Jamal al-Husseini, an active nationalist, held the position of Secretary of the Executive Committee in the Palestine Arab Congress (1921-34). He was responsible for the establishment of the al-Liwaa' newspaper and was the co-founder of the Palestine Arab Party. $\frac{56}{}$

Shahid indicated that she received her father's newspaper regularly at the FGS in the 1930s. She noted, "The mid-1930s and the situation in Palestine was coming to a boil. Even in our protected school environment, we knew about the demonstrations and strikes and began to think about politics." She explained the interest of the FGS students in receiving updates about the news and "the newspaper became more popular by the day. It was delivered in the afternoon and after classes we [the students] would rush to the outside gate to collect it, poring over it and passing it on from one group of ardent readers to another." A few days after her father's arrest by British authorities for his political activities, Serene and other FGS students "discovered that arrest was not only for criminals, and that Arab 
resistance in Palestine was being punished by the British." She continued by saying, "For us schoolgirls, this had been a political awakening. My newspaper had been our contact with the events going on outside our school life. Now, our childhood gave way to early maturity."

The students also show dedication to the Arabic language and Arab culture. They emphasized the importance of rejuvenating the Arabic language as the uniting element of Palestinian Arab nationalism. Zahwa Kashu demonstrated in her 1925 essay al-Lugha al-Arabiyya ("The Arabic Language") the important position Arabic should have in uniting her people and what role schools should have in propagating it as the official language of the country. She calls for a movement of translating Western books and scholarship into Arabic. Kashu's belief in nationalizing Arabic as the official language was also a form of resistance to the colonial impulses of missionary education that associated English with "civilizing" projects and progress. Likewise, Miriam Za'ror wrote a small soliloquy-style essay Munajat Lugha ("Language Soliloquy") about the declining status of the Arabic language. She mourned wellknown Arab nahda writers, such as Naseef al-Yazegy and Rifa'a Rafi' El-Tahtawi of the nineteenth century. The increased attention paid to the Arabic Language and Arabic culture helped foster important cultural identities within the students of FGS while still maintaining Quaker ideologies of nonviolence and neutrality.

The Palestinian struggle against the British Mandate and policies to advance the colonial Zionist project reached its height and culminated in the General Strike and the Great Arab Revolt of 1936 to 1939. During this time, Palestinian upper and middle class women began to organize themselves politically to actively challenge the policies of the British that promoted the creation of a Jewish state in Palestine. $\frac{58}{}$ Armed resistance against colonial policies was increasingly growing in momentum and posed a challenge to Quaker religious education, especially the ideal of nonviolence, which was seen by many as submissiveness.

The intense nationalist atmosphere during the Great Revolt was present in public schools, the Friends schools, and other mission schools such as Anglican English High School in Haifa. $\stackrel{59}{\text { School }}$ administrations struggled with their students who wanted to protest against the British policies. Like other missionary schools, the Quakers adopted a strict policy that prohibited students from participating in demonstrations for fear of British retaliation in the form of shutting down the Friends schools. .60 AbuGhazaleh indicated that closing schools because of students' participation in demonstrations was one of the British policies during the Great Revolt. $\underline{61}$ Additionally, students' participation in protests would undermine the Quakers' principle of neutrality and peace and would jeopardize their good relations with the British. Usually the Quakers suspended students who participated in protests for a week and asked these students to bring their parents for readmission hearings. In 1936, Superintendent Totah took a different approach in dealing with the FBS students who wished to participate in the demonstrations: he stressed that education was a nationalist obligation and his approach proved to be perceptive and well received. By 1937, the American missionaries became even more concerned about the political situation and its influence on their students. Their reports to the Friends United Meeting stressed the inherent challenge of transmitting their Christian message of peace amid political tension, especially since the number of Arab teachers with nationalist views was greater than the number of American teachers. $\underline{62}$

With the intense political situation and strong Arab and Palestinian national sentiments, the FGS students were also compelled to come to terms with a range of contradictory ideas to which they were exposed at the school. They internalized the Quakers' message of peace and sisterhood, and advocated 
for civic duty and citizenship, individualism, and the expansion of women's public roles as basic social and political ideals for their country. However, the political tensions that they encountered resulted in ambivalence concerning Palestinian/Arab nationalism. The Quaker message of peace in the midst of political upheaval and the formation of Palestinian nationalism allowed them to negotiate the political tensions in the surrounding society. They negotiated these conflicting influences by advocating for a cultural revival and the creation of good Palestinian citizens and by avoiding the political issues they saw as contradictory to the Quakers' message of pacifism and coexistence.

Palestinian Arab women acted and reacted to different social, cultural and national changes in their efforts to claim larger roles in society. Quaker teachers enforced domestic values, and encouraged students to have strong personalities and develop ethical frameworks that would help them exert change as mothers, housewives, teachers, social workers and reformers rather than encouraging them to assume roles in politics that would directly influence policy. FGS students created a middle ground between the ideologies of their teachers and the larger social contexts in which they were living. In the process, they incorporated aspects of their Quaker education that resonated with nationalist goals and translated these into ideas applicable to their local situation. They were also eager to get involved in social and philanthropic organizations where they actively took on leadership roles. They agreed with their American teachers on the importance of modern education and household skills-skills needed to become household managers, which included the budgeting of the household income. In this way, the girls' education was valued as a means for national progress.

The available archival sources and interviews conducted with former students yield authentic Palestinian voices expressing the girls' attitudes toward their school and their Quaker education. They largely envisioned their future domestic roles as mothers and housewives and interpreted them as complementary to their extended role in the public sphere. The education they received and their awareness of the accomplishments of women's movements in the Arab and Western worlds allowed many of them to argue for gender equality in the areas of education and work. They utilized the languages of domesticity and Christian piety to articulate their version of feminism and legitimized their work beyond the home by increasing their responsibilities as reformers and teachers. Moreover, the Quaker message of peace in the midst of political upheaval and the formation of Palestinian nationalism allowed them to negotiate their national identity through advocating for Arabic cultural and linguistic revival and equal citizenship in a Palestinian society that was based on unity beyond tribal, religious and localized loyalties.

\section{Notes}

1. These include: Lilly Library at Earlham College in Richmond, Indiana; Friends History Library at Swarthmore College in Swarthmore, Pennsylvania; Magill Library at Haverford College in Haverford, Pennsylvania, which includes a collection of issues of the Ramallah Messenger, a newsletter published in Providence, Rhode Island, by the American Friends that included teachers' reports from Ramallah Mission between 1903 and 1911; the FGS Historical Collection in Ramallah includes the New Light, a monthly newsletter published by Palestinian students of the FGS between 1938 and 1949, which provides a substantial amount of information about students' experiences, their ways of thinking and their perceptions of their school and teachers; Donn Hutchison, Friends Girls School Graduate Papers, personal collection, Ramallah, Palestine; Eva Rae Marshal, unpublished autobiography, Joy Hilden personal collection, Berkeley, 
California. I also interviewed twelve women who attended the FGS between the 1930s and 1950s.

2. Heather J. Sharkey, American Evangelicals in Egypt: Missionary encounters in an age of empire (Princeton: Princeton University Press, 2008); Beth Baron, The Orphan Scandal: Christian missionaries and the rise of the Muslim Brotherhood (Stanford: Stanford University Press, 2014); Ussama Makdisi, Artillery of Heaven: American missionaries and the failed conversion of the Middle East (Ithaca: Cornell University Press, 2008); Inger Marie Okkenhaug, The Quality of Heroic Living of High Endeavor and Adventure: Anglican mission, women and education in Palestine, 1888-1948 (Leiden; Boston: Brill, 2002); Afsaneh Najmabadi, "Crafting an Educated Housewife in Iran," in Remaking Women: Feminism and modernity in the Middle East, edited by Lila Abu-Lughod (Princeton: Princeton University Press, 1998); Ellen Fleischmann, "The Impact of American Protestant Mission in Lebanon on the Construction of Female Identity, 18601950," Islam and Christian-Muslim Relations 13/4 (2002): 411-26; Barbara ReevesEllington, Domestic Frontiers: Gender, reform, and American interventions in the Ottoman Balkans and the Near East (Amherst: University of Massachusetts Press, 2013).

3. Liora R. Halperin, "The Battle over Jewish Students in the Christian Missionary Schools of Mandate Palestine," Middle East Studies 50 (2014): 737-54.

4. The idea of the recreation of Israel was rooted in the American colonial imagination. For more information see Conrad Cherry, ed., God's New Israel: Religious interpretations of American destiny (Englewood Cliffs, N.J.: Prentice Hall, Inc., 1971); Hilton Obenzinger, American Palestine: Melville, Twain, and the Holy Land mania (Princeton: Princeton University Press, 1999); Lester I. Vogel, To See a Promised Land: Americans and the Holy Land in the nineteenth century (University Park: Pennsylvania State University Press, 1993); John Davis, The Landscape of Belief: Encountering the Holy Land in nineteenth-century American art and culture (Princeton: Princeton University Press, 1996); Milette Shamir, "'Our Jerusalem': Americans in the Holy Land and Protestant narratives of national entitlement," American Quarterly 55/1 (March 2003): 2960.

5. A.L. Tibawi, Arab Education in Mandatory Palestine: A study of three decades of British administration (London: Luzac, 1956), 61.

6. Sharkey, "Empire and Muslim Conversion"; Baron, The Orphan Scandal; Makdisi, Artillery of Heaven. 7. The Supreme Muslim Council Papers (1920s, 1930s, and 1950s), Abu Dees Islamic Center Archival Collection, Abu Dees, Jerusalem.

8. Rashid Khalidi, Palestinian Identity: The construction of modern national consciousness (New York: Columbia University Press, 1997).

9. Tibawi, Arab Education, 28-29.

10. Tibawi, Arab Education, 28.

11. Khalil Totah, "Education in Palestine," The Annals of the American Academy of Political and Social Science 163 (September 1932): 153.

12. Naseeb Shaheen, A Pictorial History of Ramallah (Beirut: Arab Institute for Research and Publishing, 1992), 11-31.

13. Ramallah Messenger, August 1904, 4.

14. Khalil Totah, Report to the American Friends Mission, February 17, 1941; Friendly Flashes is a monthly newsletter published by the American Friends Board of Missions in Richmond, Indiana.

15. Okkenhaug, The Quality of Heroic Living, 137; Also see Nancy Stockdale, Colonial Encounters among English and Palestinian Women (Gainesville: University Press of Florida, 2007).

16. FGS Historical Collection, Mission Booklets, 1914-1933, Ramallah, Palestine.

17. Lois Harned Jordan, Ramallah Teacher: The life of Mildred White, Quaker missionary (Richmond, Indiana: Print Press, 1995), 63. 
18. Beth Baron, The Women's Awakening in Egypt: Culture, society, and the press (New Haven; London: Yale University Press, 1994), 142, 155.

19. Ami Ayalon, The Press in the Middle East: A history (New York: Oxford University Press, 1995), 65.

20. Ellen Fleischmann, The Nation and Its "New" Women: The Palestinian women's movement 19201948 (Berkeley: University of California Press, 2003), 164.

21. "Palestine Report" (1923), FGS Historical Collection, 5; Okkenhaug, The Quality of Heroic Living, 66.

22. Ussama Makdisi, The Culture of Sectarianism (Berkeley: University of California Press, 2000), 8

23. Ela Greenberg, Preparing the Mothers of Tomorrow: Education and Islam in Mandate Palestine (Austin: University of Texas Press, 2009), 4; Fleischmann, The Nation and Its "New" Women; Najmabadi, "Crafting an Educated Housewife."

24. Greenburg, "Educating Muslim Girls," 4.

25. Najmabadi, "Crafting an Educated Housewife," 109.

26. Greenberg, Preparing the Mothers of Tomorrow, 36; Friends School News 1930, 1-3.

27. New Light, vol. 1, no. 1 (March 12, 1938). The New Light articles indicate that the students were following international events and women's movements.

28. Zahia Durbas, "Al-Tadbeer al-Manzely"/"Home Management" (July 1927). Donn Hutchison's private collection of twenty-five essays provide telling insight into the girls' thoughts and highlight the major societal issues that concerned them at the time.

29. Tafida Tarazi, "Hayaty wal-Far' al Manzeli" (My life and home economics) (1931)

30. Tarazi, "Hayaty wal-Far' al Manzeli." Translated by the author.

31. Nazeha Abdul Jawad, interview, July 17, 2006. Her husband would later become the mayor of alBireh and a well-known Palestinian nationalist.

32. Jawad, interview, July 17, 2006.

33. Katrina Hallaby, "Wojubb Musharakat al-Mara`al-Rajul fi al-`amal" (The obligation of women's participation in the workforce with men) (July 1927).

34. Elizabeth Thompson, Colonial Citizens: Republican rights, Paternal privilege, and gender in French Syria and Lebanon. (New York: Columbia University Press, 2000), 95, 142.

35. Nancy M. Forestell and Maureen Anne Moynagh, Documenting First Wave Feminisms (Toronto: University of Toronto Press, 2012), 209.

36. Alice Houssa, "What an Educated Girl Can Do for Palestine" (July 1922).

37. Margot Badran and Miriam Cooke, Opening the Gates: An anthology of Arab feminist writing, second ed. (Bloomington: Indiana University Press, 1990), 240, 243.

38. Adnan Abu-Ghazaleh, "Arab Cultural Nationalism in Palestine during the British Mandate," Journal of Palestine Studies 1/3 (Spring 1972), 39

39. For more details see Enaya Othman, Negotiating Palestinian Womanhood: Encounters between Palestinian women and American missionaries, 1880s-1940s (Lexington: Rowman and Littlefield Press, 2016).

40. Jordan, Ramallah Teacher, 78.

41. McDowell, Notes from Ramallah, 62.

42. Aida Audi, interview, July 28, 2006.

43. Badran and Cooke, Opening the Gates, 240, 243.

44. Luryce Kassab, "Num 'w al-shu'ur al-Watany" (The growth of national sentiments) (July 1925).

45. For more information about women and family in the Arab world see Suad Joseph, "Gender and Family in the Arab World," in Arab Women between Defiance and Restraint, edited by Suha Sabbagh (New York: Olive Branch Press, 1996).

46. Najla Cook, interview, July, 27, 2006.

47. This school for orphans taught mainly agriculture and home economics. 
48. New Light, 1938. Margaret Jubrial had wanted to become a dentist, but because of financial limitations, she turned to her second choice.

49. New Light, 1938.

50. New Light, 1949.

51. Marshal, unpublished autobiography, 41.

52. Friends Schools News, no. 3 (November 1932), FGS Historical Collection, Ramallah, Palestine, 4; Eva Rae Marshal, Letter to her Family (September 30, 1928).

53. Salwa Tabri, interview, July 18, 2006; Audi, interview, July 28, 2006.

54. Ghayda Salah. "Yusra Salah. 1923-1993," Darat al-maarif al-filistiniyh (Palestinian encyclopedia) (n.d.), http://ency.najah.edu/node/17; Ela Greenberg, Preparing the Mothers of Tomorrow, 23, 185-86.

55. Fleischmann, The Nation and Its "New" Women.

56. Serene Husseini Shahid, Jerusalem Memories, edited by Jean Said Makdisi (Beirut: Naufa, 2000), 76.

57. Shahid, Jerusalem Memories, 76, 79.

58. For more information see Fleischmann, The Nation and Its "New" Women.

59. Elizabeth Brownson, "Colonialism, Nationalism, and the Politics of Teaching History in Mandate Palestine," Journal of Palestine Studies 43/3 (Spring 2014): 18.

60. Ramallah Mission Minutes, June 1946.

61. Abu-Ghazaleh, "Arab Cultural Nationalism in Palestine," 42-43.

62. FGS Report 1937. 